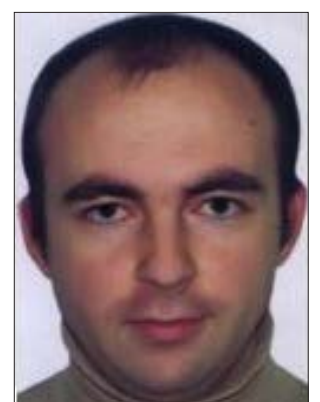

Oleksandr P. Klochkov

О. П. Клочков

УДК 629.58

\title{
THE PROJECT TASKS OF SINGLE LINK SELF-PROPELLED TETHERED UNDERWATER SYSTEMS ENERGY SUPPLY
}

\section{ПРОЕКТНІ ЗАДАЧІ ЕНЕРГОЖИВЛЕННЯ ОДНОЛАНКОВИХ САМОХІДНИХ ПРИВ' ЯЗНИХ ПІДВОДНИХ СИСТЕМ}

DOI https://doi.org/10.15589/smi2019.1(11).11

Oleksandr P. Klochkov

О. П. Клочков, ст. викл.

oleksandr.klochkov@nuos.edu.ua

ORC ID: 0000-0002-6426-3374

\section{Admiral Makarov National University of Shipbuilding, Mykolaiv \\ Національний університет кораблебудування імені адмірала Макарова, м. Миколаӥв}

Abstract. Purpose. An approach to designing a self-propelled attached underwater system in the early stages, which involves taking into account the material, energy, information and functional components, the quantitative parameters of which are provided by the customer in the technical task, which are considered as limitations when using the system approach is provided. Method. A separation of individual structural elements, the power of which can be measured or calculated, in the composition of a self-propelled attached underwater system is made. The maximum power of each element depending on the set of system operation modes is determined. A comparison of the sum of the maximum powers of the structural elements of the system with the power specified in the terms of reference is made. Results. The design problems of power supply for a single-link self-propelled attached underwater system related to the issue of the transfer of electric energy from a carrier vessel to a self-propelled attached underwater vehicle are considered. The essential influence of the optimal cable length and its diameter on the parameters of providing electric power to the underwater vehicle is explained. A block diagram of the algorithm, according to which it is recommended to make a decision on the creation of a self-propelled tethered underwater system in the early stages of design is proposed. Scientific novelty. There is a division of electrical consumers into four groups, which implies taking into account the electric power of not only the propulsion and steering complex of the underwater vehicle, which is variable from the operating mode, but also the electric power of the consumers of the vehicle, which are statically in its composition, attachments and deck equipment carrier ship. The latter provides direct transmission of electrical energy through a cable-tether, the operation and maintenance of the underwater vehicle during the entire process of performing underwater technical work. When considering the operating modes of the propulsion and steering complex, the case was taken into account when the propulsion and steering device consumes the greatest electric power for itself, although the operating mode of the entire propulsion and steering complex is not the most energy-intensive. Practical importance. The approach can be used as an algorithm for assessing the possibility of creating a selfpropelled tethered underwater system in the early stages of its design.

Key words: technical task, self-propelled tethered underwater vehicle, cable-tether, system approach, equation of existence, propulsion and steering complex.

Анотація. Мета. Наведено підхід до проектування самохідної прив'язної підводної системи на ранніх стадіях, що передбачає врахування матеріального, енергетичного, інформаційного та функціонального складників, кількісні параметри яких подані замовником у технічному завданні, що розглядаються як обмеження під час використання системного підходу. Методика. Виконано виділення у складі самохідної прив'язної підводної системи окремих структурних елементів, потужність яких можливо виміряти чи вирахувати. Визначена максимальна потужність кожного елемента залежно від множини режимів роботи системи. Здійснено порівняння суми максимальних потужностей структурних елементів системи з потужністю, що задана у технічному завданні. Результати. Розглянуто проектні задачі енергоживлення одноланкової самохідної прив'язної підводної системи, що пов'язані з питанням передачі електричної енергії від судна-носія до самохідного прив'язного підводного апарата. Пояснено суттєвий вплив оптимальної довжини кабель-троса та його діаметра на параметри забезпечення підводного апарата електричною енергією. Запропонована блок-схема алгоритму, за яким має відбуватися прийняття рішення 
про створення самохідної прив'язної підводної системи на ранніх стадіях проектування. Наукова новизна. Передбачено поділ електричних споживачів на чотири групи, що передбачає врахування електричної потужності не тільки рушійно-рульового комплексу підводного апарата, що є змінною від режиму роботи, а ще електричної потужності споживачів постійного складу апарата, начіпного обладнання та палубного обладнання судна-носія, що забезпечує безпосередню передачу електричної енергії через кабель-трос і функціонування та обслуговування підводного апарата протягом усього процесу виконання підводнотехнічної роботи. Під час розгляду режимів роботи рушійно-рульового комплексу враховано випадок, коли рушійно-стерновий пристрій споживає найбільшу для себе електричну потужність, хоча режим роботи всього рушійно-рульового комплексу при цьому не є найбільш енерговитратним. Практична значимість. Підхід може бути використано як алгоритм до оцінки можливості створення самохідної прив'язної підводної системи на ранніх стадіях іiі проектування.

Ключові слова: технічне завдання, самохідний прив'язний підводний апарат, кабель-трос, системний підхід, рівняння існування, рушійно-рульовий комплекс.

\section{References}

[1] Ryzhkov, S.S. (Ed.). (2011). Stvorennia universalnykh transportnykh suden i zasobiv okeanotekhniky [Creation of universal transport vessels and means of ocean engineering] (monohrafiia). Mykolaiv: Vydavnytstvo NUK (in Ukrainian).

[2] Sulaiman, O., \& Saharuddin A. (2012). Power integrity requirement of new generation of ROV for deep sea operation. Global Journal of Researches in Engineering Automotive Engineering, 12 (3-B), 16-28.

[3] Brilliantov, A.N. (2005). Razrabotka i issledovanie osnov postroeniya energeticheskikh sistem podvodnykh apparatov [The development and research of the fundamentals of building energy systems of underwater vehicles] (Avtoreferat dissertatsii kandidata tekhnicheskikh nauk). Moscow : Rossiyskaya akademiya nauk, institut okeanologii im. P.P. Shirshova (in Russian).

[4] Filozhenko, A.Yu. (2010). Sistema elektrosnabzheniya privyaznykh neobitaemykh podvodnykh obektov [The power supply system for tethered uninhabited underwater objects] (Avtoreferat dissertatsii kandidata tekhnicheskikh nauk). Vladivostok: Institut problem morskikh tekhnologiy DVO RAN (in Russian).

[5] Pravikova, A.A., Rulevskiy, V.M., Lyapunov, D.Yu., \& Bukreev, V.G. Matematicheskaya model sistemy elektropitaniya teleupravlyaemogo podvodnogo apparata s peredachey energii po kabel-trosu na peremennom toke [The mathematical model of a power supply system for a remote-controlled underwater vehicle with transmission of energy via an alternating current cable]. Elektrotekhnika, doklady TUSURa, 20 (1), 131-135 (in Russian).

[6] Blintsov, O. V. (2017). Rozrobka metodu matematychnoho modeliuvannia dynamiky hnuchkoho zv’iazku yak elementa pidvodnoho kompleksu [Development of the mathematical modeling method for dynamics of the flexible tether as an element of the underwater complex]. Eastern-European Journal of Enterprise Technologies, 1/7 (85), 4-14. doi: 10.15587/1729-4061.2017.90291 (in Ukrainian).

[7] Blintsov, V.S. (2007). Sovremennye problemy sozdaniya elektrooborudovaniya i avtomatiki podvodnykh apparatov [The modern problems of creating electrical equipment and automation of underwater vehicles]. Radioelectronic and computer systems, 5 (24), 90-98 (in Russian).

[8] Babkin, H.V. (2017). Upravlinnia uspishnymy proektamy stvorennia skladnoi tekhniky [The management of successful projects of complex technology creation] (monohrafiia). Mykolaiv : Vydavnytstvo Torubary V.V. (in Ukrainian).

[9] Blintsov, A.V. (2012). Spetsializirovannyy modeliruyushchiy kompleks dlya issledovaniya effektivnosti sistemy upravleniya podvodnoy buksiruemoy sistemoy [A specialized modeling complex for studying the effectiveness of the control system of an underwater towed system]. Collection of Scientific Papers of Admiral Makarov National University of Shipbuilding, 1 (442), 92-97 (in Russian).

[10] Blintsov, V.S., \& Magula, V.E. (1997). Proektirovanie samokhodnykh privyaznykh podvodnykh sistem [The design of self-propelled tethered underwater systems]. Kiev : Naukova dumka (in Russian).

[11] Yegorov, V.I. (1981). Podvodnye buksiruemye sistemy [The towed underwater systems] (uchebnoe posobie). Leningrad : Sudostroenie (in Russian).

[12] Blintsov, V.S. (1991). Osobennosti proektirovaniya kabel-trosov privyaznykh podvodnykh apparatov [The design features of remote underwater vehicles cable-tethers]. Proektirovanie sredstv osvoeniya okeana, 76-79 (in Russian).

[13] Blintsov, V., \& Klochkov, O. (2019). Generalized method of designing unmanned remotely operated complexes based on the system approach. EUREKA: Physics and Engineering, 2, 43-51. doi:10.21303/2461-4262.2019.00878.

[14] Blintsov, V.S. (2016). Rivniannia isnuvannia samokhidnoi pryv’iaznoi pidvodnoi systemy yak otsinka mozhlyvosti yii stvorennia [The equations of self-propelled underwater system existence as an estimation of possibility of its creation]. Underwater technologies: industrial and civil engineering, 3, 25-30 (in Ukrainian). 
Постановка проблеми. Одноланкові самохідні прив'язні підводні системи (СППС) широко використовуються для виконання великого різноманіття підводно-технічних робіт (ПТР) на різних глибинах [1]. 3 кожним роком удосконалення таких систем передбачає передачу все більшої кількості електричної потужності через кабель-трос (КТ) до самохідного прив'язного підводного апарата (СППА). Особливо це помітно у випадку, коли проведення ПТР супроводжується ускладненими гідро- та метеорологічними умовами. Так, значні вітрохвильові збурення чи сильні підводні течії вимагають збільшення упорів електрорушійних пристроїв та, відповідно, потужності їх електроприводів.

На цей час відсутня єдина методологія проектування систем енергоживлення СППС, яка б враховувала особливості його експлуатації як системи твердих і гнучких складників, що мають силову взаємодію у потоці води. При цьому така взаємодія не розглядається на всій множині робочих і аварійних режимів з урахуванням взаємної залежності енергетичних характеристик ії складників у цих режимах.

У зв'язку із цим актуальними $є$ наукове завдання виявлення таких залежностей, їх формалізація на основі системного підходу та побудова науково обгрунтованої методики проектування системи енергоживлення СППС з урахуванням енергетичної взаємодії іiі складників.

Особливу актуальність така постановка проблеми проектування СППС набуває внаслідок необхідності визначати можливість створення нових засобів підводної робототехніки вже на ранніх стадіях ії̈ проектування, оскільки це скорочує загальну вартість проектних робіт.

Аналіз останніх досліджень i публікацій. Питання розробки систем енергоживлення належить до ключових під час проектування СППС, оскільки від ефективності прийнятих технічних рішень залежить продуктивність виконання ПТР. Указаним питанням присвячено значну кількість наукових досліджень. Так, у роботі [2] розглядається питання електроживлення обладнання та інструменту СППА на основі гідравлічних систем на великих глибинах.

В авторефераті дисертації [3] висвітлені питання впливу на параметри енергоживлення прив'язних підводних систем не тільки елементів системи, а ще і зовнішніх факторів із заходами мінімізації енерговитрат.

А в авторефераті дисертації [4] детально описано та пояснено принципи схем енергоживлення підводних об'єктів, які отримують електричне живлення шляхом використання кабель-троса.

Відомі наукові школи зі створення прив'язної підводної техніки у своїх доповідях [5] за допомогою математичних моделей надають оцінку кількісним показникам електричних параметрів під час енергоживлення такого виду техніки.

У всіх описаних джерелах питання проектування енергетичного забезпечення одноланкової прив'язної підводної системи розглядається за окремими аспектами, що є елементами системного підходу на ранніх етапах створення такого виду техніки, але загального підходу, який би враховував усі чинники проектування та їхній вплив один на одного, не розглядається.

Відокремлення не вирішених раніше частин загальної проблеми. 3 огляду на те, що загальною проблемою $є$ проектування СППС, яке передбачає досягнення виправданих технічних рішень 3 точки зору економічного та експлуатаційного складників стосовно їі створення й використання, можливо виділити наступні частини загальної проблеми, які потребують вирішення:

відокремлення окремих функціональних груп СППС із метою визначення їх максимальних електричних потужностей з певною точністю залежно від режиму роботи СППА та системи загалом;

- пошук оптимального рішення відносно проектування КТ як основного чинника виникнення взаємно суперечливих аспектів, що пов'язані $з$ передачею через нього електричної потужності до СППА;

складання алгоритму для використання на ранніх стадіях проектування СППС на основі системного підходу з можливістю попередньої оцінки iii створення, в якому робиться акцент, що без забезпечення енергетичного складника підходу розгляд матеріального, інформаційного та функціонального складників не є доцільним без коригування технічного завдання.

Мета дослідження - удосконалення методики проектування систем енергоживлення одноланкової самохідної прив'язної підводної системи на основі системного підходу шляхом урахування силової взаємодії твердих і гнучких тіл СППС у потоці води.

Для досягнення поставленої мети необхідно розв'язати наступні задачі:

- отримати основні енергетичні залежності для складників СППС як основу для рівняння енергетичного балансу СППС, яка створюється;

- установити множину основних експлуатаційних режимів СППС, які мають високе енергоспоживання, та визначити порядок їх урахування у проектних розрахунках енергоживлення СППС;

- отримати залежності для конструктивних параметрів кабель-троса самохідного прив'язного підводного апарата, що впливають на енергетичні характеристики СППС;

- адаптувати отримані енергетичні залежності як складники узагальненої методики проектування безекіпажних самохідних прив'язних підводних комплексів на основі системного підходу.

Методи, об'скт та предмет дослідження. Предмет дослідження - вплив експлуатаційного параметра, а саме електричної потужності складників СППС на їі конструктивні характеристики. При цьому кількісні значення експлуатаційних параметрів та конструктивних характеристик подані замовником у технічному завданні. 
об'єктом дослідження є СППС та системний підхід до іiі проектування на ранніх стадіях iï створення.

Метод дослідження полягає у порівнянні кількісних значень параметрів, які можуть бути пораховані на базі реальних об'єктів функціонування СППС, $з$ кількісними значеннями цих параметрів, що задані у технічному завданні. У випадку неможливості отримання значення у межах, що диктуються умовами технічного завдання, відбувається пошук технічних, які задовольняють ці умови, або, за можливості, коригується технічне завдання за згодою замовника. Ітерації відбуваються до тих пір, поки не відбувається перехід до наступного етапу проектування, що підтверджується відповідними технічними рішеннями $з$ наведенням основних розрахунків та моделюванням, а також економічною доцільністю.

\section{Основний матеріал}

\section{1. Основні енергетичні залежності СППС}

У класичному уявленні складниками одноланкової самохідної прив'язної підводної системи є СППА, пост енергетики та керування (ПЕК), КТ, кабельна лебідка (КЛ) і спуско-піднімальний пристрій (СПП). Якщо СППС базується на безекіпажному судні як носії підводної системи, то до об'єктів автоматизації відносять також судно-носій $(\mathrm{CH})$. У загальному випадку місцем базування для такого різновиду підводних систем також може бути підводний човен, гвинтокрил, пересувна платформа, берегова база тощо. Склад СППС, що базується на $\mathrm{CH}$, наведено на рис. 1.

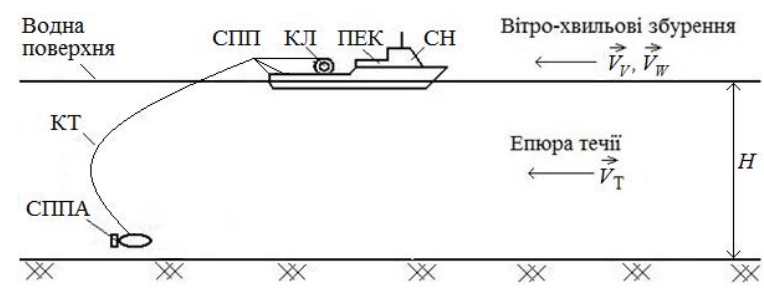

Рис. 1. Склад одноланкової самохідної прив'язної підводної системи з базуванням на судні-носії

Спираючись на досвід автора у проектуванні, створенні та морській експлуатації СППС, можна стверджувати, що від правильності проектних рішень щодо енергетичного забезпечення такої системи суттєво залежить ефективність ії використання, зокрема, продуктивність і якість виконання підводних робіт. Так, дефіцит потужності впливає на швидкість підводного руху СППА в граничних режимах та якість роботи його підводної відео- і гідроакустичної апаратури.

Оскільки енергоживлення СППС забезпечується від бортового джерела енергії СН (зазвичай його електростанції), має місце залежність

$$
P_{\text {СппС }} \leq P_{\text {тз }}=k_{\text {СппС }} \cdot P_{C H},
$$

де $P_{\text {Сппс }}$ - потужність, що споживається СППС у складі ПЕК, КЛ, СПП та СППА; $P_{\text {тз }}$ - потужність СППС, задана у технічному завданні на створення прив'язної системи; $k_{\text {сппс }}-$ коефіцієнт відбору потужності на потреби СППС від суднової електростанції потужністю $P_{C H}$.

Залежність (1) є рівнянням енергетичного балансу СППС, що створюється і має використовуватися у проектній методиці як базова, що гарантує можливість побудови такої системи за вимогами технічного завдання.

Своєю чергою величина $P_{\text {сппс }}$ формується як сума потужностей, що споживаються складниками СППС - ПЕК, КТ, КЛ, СПП та СППА (індекси при змінних збігаються з абревіатурами складників):

$$
P_{\text {СПпС }}=P_{\text {ПЕК }}+P_{\text {КТ }}+P_{\text {Кл }}+P_{\text {СПП }}+P_{\text {СППА }}
$$

Розглянемо послідовно особливості енергозабезпечення цих складників.

До основних завдань ПЕК належать енергопостачання та керування (ручне, автоматизоване чи автоматичне) виконавчими складниками СППС (КЛ, СПП і СППА) у нормальних та аварійних режимах. У зв'язку із цим основними складниками енергоживлення ПЕК є наступні потужності:

$$
P_{\text {ПЕК }}=P_{\text {ПЕКО }}+P_{\text {ПЕКЕ }}
$$

де $P_{\text {пеко }}-$ потужність, необхідна для забезпечення роботи внутрішнього обладнання ПЕК (пультів керування СППС та систем зв'язку, освітлення й кондиціонування приміщення, освітлення робочої палуби СН тощо); $P_{\text {пекЕ }}$ - потужність обладнання ПЕК, яке забезпечує енергоживлення КЛ, СПП та СППА (обладнання розподілу електроенергії між споживачами, електричні апарати захисту і сигналізаціі).

Призначення КТ полягає у передачі електроенергії до СППА, а також у забезпеченні обміну інформацією між СППА та ПЕК. Крім того, КТ виконує функції вантажного елемента, який забезпечує силову взаємодію між СППА та КЛ, які працюють в умовах потоку води, що набігає на СППА і КТ (підводна течія, синхронний рух СППА та його СН тощо). Таким чином, вплив КТ на енергетику СППС необхідно розглядати у вигляді двох основних складників:

- втрати потужності $\Delta P_{\text {кт }}$ унаслідок протікання електричного струму $I_{\text {сппА }}$ по силових жилах КТ при електроживленні СППА;

- необхідності передавати через КТ енергію для електричних двигунів рушійно-рульового комплексу (РРК) СППА, які своїми упорами $T$ мають подолати не тільки гідродинамічний опір власне СППА $F_{\text {СПпА }}$, а й гідродинамічний опір КТ $F_{\text {Кт }}$

Перший складник визначається залежностями відповідно для постійного та трифазного змінного струмів:

$$
\Delta P_{\text {КТ }}=R \cdot I_{\text {СППА }}^{2}
$$




$$
\Delta P_{\text {Кт }}=3 R \cdot I_{\text {СПпА }}{ }^{\phi},
$$

де $R$ - електричний опір силової жили КТ; індекс «ф» означає фазні значення напруги живлення та струму.

Другий складник впливу КТ на енергетику СППС має гідродинамічну природу і суттєво залежить від просторової форми КТ та його гідродинамічних характеристик, а також від швидкості потоку води, що набігає. У зв'язку із цим іiі обрахування зазвичай виконують із залученням методів математичного та комп'ютерного моделювання [6]. Результатом такого обрахування $є$ вектори сил $\vec{F}_{\text {Кт1 }}$ i $\vec{F}_{\text {Кт2 }}$, які утворюються відповідно на корінному й ходовому кінцях КТ. Вектор $\vec{F}_{\text {Кт2 }}$ долається упорами РРК.

Споживана потужність КЛ складається з потужності $P_{\text {дкл }}$ електропривода її кабельного барабана та потужності $P_{\text {дку }}$ електропривода укладача КТ на барабан, а також потужності $P_{\text {пкл }}$ приладів контролю і сигналізації лебідки (електрогальмівного механізму, давачів швидкості обертання кабельного барабана та натягу КТ тощо):

$$
P_{\text {кл }}=P_{\text {дкл }}+P_{\text {дку }}+P_{\text {пкл }}
$$

Споживана потужність СПП складається 3 потужності електропривода $P_{\text {кспп }}$ повороту кран-балки (чи нахилу вантажної рами, якщо СПП має рамну конструкцію), потужності електропривода $P_{\text {гспп }}$ опускання / піднімання вантажного гака, потужності

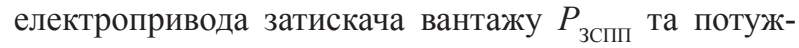
ності $P_{\text {пспп }}$ приладів контролю і сигналізації СПП (електрогальмівного механізму, давачів кута повороту кран-балки чи вантажної рами, натягу КТ тощо):

$$
P_{\text {спп }}=P_{\text {кспп }}+P_{\text {гспп }}+P_{\text {зспп }}+P_{\text {пспп }} .
$$

Найбільшу складність під час проектних розрахунків СППС має оцінка потужності СППА $P_{\text {СПпА }}$ оскільки саме він $є$ головним виконавчим механізмом підводної системи і режими його функціонування визначають в основному споживану потужність усієї системи.

Досвід автора у проектуванні СППС свідчить про доцільність оцінки величини $P_{\text {СппА }}$ як суми потужностей трьох основних груп споживачів електроенергії:

- потужності бортового електрообладнання СППА $P_{\text {Б }}$, величина якої залишається практично незмінною протягом усього часу проведення підводної місії (до такого обладнання відносять фото- і відеокомплекси із системами підводного освітлення, штатні гідроакустичні прилади, пристрої системи ручного й автоматичного керування, системи телеметрії та зв'язку СППА з ПЕК тощо);

- п потужності РРК $P_{\text {РРК }}$;

- потужності начіпного обладнання СППА $P_{\mathrm{H}}$, призначеного для виконання інструментальних підводних робіт (до такого обладнання належать підводні маніпулятори, грунторозмивачі, різаки тросів, потужні пошукові гідроакустичні прилади тощо).

Таким чином, споживану потужність СППА характеризує відношення

$$
P_{\text {СППА }}=P_{\mathrm{b}}+P_{\mathrm{PPK}}+P_{\mathrm{H}} \text {. }
$$

Потужність $P_{\text {Б }}$ зазвичай визначається як проста сума потужностей елементів бортового електрообладнання [7] і особливих складнощів під проектування СППА не викликає.

Величина потужності $P_{\mathrm{H}}$, споживаної начіпним обладнанням СППА, залежить від конкретного режиму підводної роботи, однак у проектній практиці і1ї враховують у вигляді номінального (паспортного) значення.

Потужність, споживана РРК, є визначальною під час проектних оцінок потужності більшості типів СППА, тому розглянемо процес ії розрахунку більш детально.

Конфігурація РРК та кількість рушійних пристроїв (РП), що входять до його складу, мають забезпечувати маршовий, вертикальний і лаговий рухи СППА.

Будемо розглядати РРК у складі двох маршових (лівого МЛ і правого МП), одного вертикального В та одного лагового Л рушійних пристроїв. Відповідно вказані рушії споживають електроенергію та розвивають потужність $P_{x}=\left(P_{x м л}+P_{x м \Pi}\right)$ для поздовжнього руху СППА (вісь $x$ у системі координат, зв'язаній з корпусом апарата), а також потужності $P_{y}$ та $P_{z}$ для вертикального і лагового рухів апарата (відповідно осі у та $z$ у системі координат, зв'язаній 3 корпусом апарата).

Залежно від режиму роботи СППА електрична потужність, яка споживається РРК, є змінною величиною.

\section{2. Основні експлуатаційні режими СППС}

3 метою забезпечення найбільш енерговитратного режиму РРК (робота з максимальною потужністю $\left.P_{\text {PРКmax }}\right)$ проаналізуємо $N$ експлуатаційних режимів СППА і визначимо ті з них, для яких необхідно розвивати максимальну потужність РП за одною з осей. У цьому випадку режим обирається за максимальним упором, що визначається 3 множини упорів для кожного з РП під час розгляду всіх режимів роботи PРК:

$$
\begin{aligned}
& P_{x \max }=\sup \left\{P_{x 1} ; \ldots P_{x i} ; \ldots ; P_{x N}\right\} \\
& P_{y \text { max }}=\sup \left\{P_{y 1} ; \ldots P_{y i} ; \ldots ; P_{y N}\right\} . \\
& P_{z \max }=\sup \left\{P_{z 1} ; \ldots P_{z i} ; \ldots ; P_{z N}\right\}
\end{aligned}
$$

Знайдені потужності РП по осях $x, y, z$ визначають установлену потужність гребних електродвигунів, яку треба закладати у проект СППА.

Далі, для визначення максимального значення потужності $P_{\text {РPКтаx }}$, споживаної РРК у найбільш важкому режимі роботи, необхідно обрахувати потужності $P_{\text {РРКi }}=\left(P_{x i}+P_{y i}+P_{z i}\right)$ для кожного з $N$ режимів та обрати максимальну з них: 


$$
P_{\mathrm{PPK} \max }=\sup \left\{P_{\mathrm{PPK} 1} ; \ldots P_{\mathrm{PPK} i} ; \ldots ; P_{\mathrm{PPKN}}\right\} .
$$

Ураховуючи вищенаведене, переходимо до аналізу режимів роботи СППС у цілому. Для кожного режиму роботи системи потужність, що споживається кожним іiі складником, є різною. Наведемо перелік типових режимів роботи СППС:

а) перевірка працездатності обладнання системи на палубі;

б) опускання СППА з палуби СН на воду та, відповідно, підйом СППА на борт СН;

в) рух СППА по поверхні води та занурення у визначеній точці (альтернативний режим - занурення СППА та його підводний рух до визначеної точки підводного простору - залежно від навігаційної обстановки);

г) плоский та/чи просторовий рух СППА складними траєкторіями;

д) прямолінійний чи криволінійний рух СППА під час проведення ПТР на протяжному об'єкті;

е) маневрування та просторове позиціонування СППА під час виконання ПТР на точковому об'єкті.

Після аналізу режимів роботи визначається множина значень потужності для кожного складника СППС, з якої за аналогією з (10) обирається максимальна $-\sup \left(P_{\text {ПЕК } i \ldots N}\right), \sup \left(P_{\text {КТ } i \ldots N}\right), \sup \left(P_{\text {клi...N }}\right)$, $\sup \left(P_{\text {Сппі...N }}\right)$. Виходячи із цих максимальних значень проектується кожний складник СППС.

Що ж стосується максимального значення потужності $P_{\text {сппс }}$, яка відбирається від електростанції $\mathrm{CH}$, то іï значення визначається як максимальне значення сумарної споживаної потужності $P_{\text {сппс }} 3$ множини $N$ режимів роботи СППС. Як приклад у табл. 1 наведено значення потужностей для СППС одного 3 проектів, який розроблявся у Національному університеті кораблебудування імені адмірала Макарова за участю автора статті [8].

Таким чином, за варіантом СППС, що розглядається, отримуємо значення максимальної споживаної потужності $P_{\text {Сппс }}=44,8$ кВт.

Для отримання кількісних показників для системи залежностей (9) і табл. 1 проектувальник має виконати масові розрахунки системи «СППА-КТ» для всієї множини режимів підводного руху системи. Такі розрахунки зазвичай виконуються із застосуванням спеціальних моделюючих комплексів або прикладних пакетів програм [9].

3. Визначення конструктивних параметрів кабель-троса СППА, що впливають наенергетичні характеристики СППС

Розглянемо тепер характер взаємодії СППА як твердого тіла і КТ як гнучкого тіла, що мають силову взаємодію між собою у потоці води, та визначимо аналітичні залежності такої взаємодії.

Відомо, що гідродинамічні характеристики КТ суттєво впливають на вектор сил, які прикладені до корпусу СППА [10]. У більшості проектних задач СППС, призначених для роботи навіть на малих (до 100 метрів) глибинах в умовах підводної течії, склад-
Таблиця 1. Значення потужностей, що споживаються СППС проекту «КНПА», в основних режимах роботи

\begin{tabular}{|c|c|c|c|c|c|c|}
\hline \multirow{2}{*}{$\begin{array}{c}\text { Найменування } \\
\text { режиму }\end{array}$} & $P_{\text {ПЕк }}$ & $\Delta P_{\text {кт }}$ & $P_{\text {кл }}$ & $P_{\text {Спп }}$ & $P_{\text {СппА }}$ & $P_{\text {СПпС }}$ \\
\cline { 2 - 7 } & \multicolumn{7}{|c|}{ кВ Т } \\
\hline а) & 1,1 & 0,03 & - & - & 1,36 & 2,49 \\
\hline б) & 1,1 & - & 1,3 & 9,2 & - & 11,60 \\
\hline в) & 1,1 & 1,50 & 3,5 & - & 15,00 & 21,10 \\
\hline г) & 1,1 & 3,00 & 13,2 & - & 27,50 & 44,80 \\
\hline д) & 1,1 & 3,00 & 13,2 & - & 27,50 & 44,80 \\
\hline е) & 1,1 & 3,00 & 6,6 & - & 13,70 & 24,40 \\
\hline
\end{tabular}

ник гідродинамічного опору КТ $F_{\text {Кт }}$ є визначальним під час розрахунків упорів рушіїв СППА і сягає $90 \%$ від їх абсолютного значення. Тому розрахунки вектора сили $\vec{F}_{\text {кт }}$ мають бути віднесені до головних складників процесу проектних оцінок системи енергоживлення СППА.

Відомо, що гідродинамічний опір $f_{\text {кт }}$ одиниці довжини КТ прямо пропорційно залежить від його діаметра $d_{\text {кт }}$ і коефіцієнта гідродинамічного опору $C$ та квадратично залежить від швидкості потоку води $v$, що набігає на КТ [11]:

$$
\begin{aligned}
& f_{\mathrm{KT} n}=0,5 \cdot C_{n} \cdot \rho \cdot v_{\mathrm{n}}^{2} \cdot d_{\mathrm{KT}} ; \\
& f_{\mathrm{KT} t}=0,5 \cdot C_{t} \cdot \rho \cdot v_{\mathrm{t}}^{2} \cdot d_{\mathrm{KT}} ; \\
& f_{\mathrm{KT} b}=0,5 \cdot C_{b} \cdot \rho \cdot v_{b}^{2} \cdot d_{\mathrm{KT}},
\end{aligned}
$$

де $n, t, b$ - індекси відповідно нормального, дотичного та бокового складників гідродинамічного опору КТ; $\rho$ - питома густина води.

Разом 3 тим передача електроенергії за допомогою КТ призводить до спаду напруги $\Delta U_{\text {Кт }}$, яка живить електрообладнання СНПА. Обмеження на величину $\Delta U_{\text {кт }}$, викликані вимогами до якості електроживлення цього обладнання, призводять до збільшення діаметра силових жил КТ і, як наслідок, до збільшення значення $d_{\text {кт }}$ і зростання гідродинамічного опору КТ. Сдиним шляхом зменшення проектних значень $d_{\mathrm{\kappa T}} \epsilon$ підвищення напруги живлення СППА, проте таке підвищення призводить до зростання товщини електричної ізоляції КТ та у зв'язку із цим до зростання величин $d_{\mathrm{KT}}$ i $F_{\mathrm{KT}}[12]$.

Тому під час проектування систем енергозабезпечення СППА необхідно шукати оптимальне співвідношення між гідродинамічними та електричними характеристиками КТ.

Наведемо основні аналітичні залежності, які пов'язують ці характеристики.

Величину $d_{\text {кт }}$ можна обчислити за формулою

$$
\begin{gathered}
d_{\mathrm{KT}}=k_{C L} \cdot d_{E W}+2 \delta_{E I}+2 \delta_{P S} ; \\
d_{E W}=d_{E}+2 \delta_{I},
\end{gathered}
$$

де $k_{C L}$ - коефіцієнт укладання елементів конструкції сердечника КТ (силових та інформаційних електричних провідників, вантажних елементів 
і елементів плавучості КТ), який пов'язує уніфіковані діаметри $d_{E W}$ цих елементів 3 діаметром сердечника КТ; $\delta_{E I}-$ товщина зовнішньої ізоляції сердечника КТ; $\delta_{P S}-$ товщина зовнішньої захисної оболонки КТ; $d_{E}$ i $\delta_{I}-$ відповідно діаметр силового провідника електричного струму КТ та товщина його електричної ізоляції.

Величина електричної напруги живлення СППА $U_{\text {сппа }}$ суттєво впливає на діаметр КТ, оскільки за за-

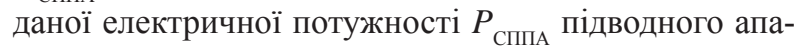
рата діаметр $d_{E W}$ залежить від площі поперечного перерізу силового провідника електричного струму $S_{E}$ та товщини його електричної ізоляції $\delta_{I}$ :

$$
d_{E W}=2 \cdot \sqrt{\frac{s_{E}}{\pi}}+2 \cdot \delta_{I},
$$

а величина $S_{E}$ пов'язана з електричною напругою $U_{\text {СппА }}$ залежністю

$$
s_{E}=\frac{P_{\text {СППА }}}{j_{E} \cdot U_{\text {СППА }}},
$$

де $j_{E}$ - щільність електричного струму силового провідника КТ, обрана з урахуванням обмеження на величину $\Delta U_{\text {кт }}$.

Залежності (11)-(15) можуть бути покладені в основу розрахунку конструкції КТ, діаметр якого забезпечить мінімальний гідродинамічний опір у потоці води, що набігає.

4. Адаптація отриманих енергетичних залежностей як складника узагальненої методики проектування безекіпажних самохідних прив'язних підводних комплексів на основі системного підходу

Узагальнена методика проектування безекіпажних самохідних прив'язних підводних комплексів (СППК) на основі системного підходу детально розглянута у [13]. У іï основу покладено використання системи рівнянь існування СППК, які дають змогу системно оцінювати проектні рішення за матеріальними $M$, енергетичними $E$, інформаційними $I$ та експлуатаційними $F$ критеріями. Це дає змогу вже на ранніх стадіях проектування встановити можливість створення підводної робототехніки із заданими замовником характеристиками.

На ii основі розглянемо алгоритм визначення можливості створення СППС на ранніх стадіях проектування за критерієм енергоживлення (рис. 2).

Базою, що визначає можливість створення СППС на ранніх стадіях проектування, є технічне завдання (Т3), яке надається замовником (блок 1 на рис. 2). Тут задаються кількісні характеристики майбутнього СППК, зокрема: напруга $U_{\text {сппА }}$ та частота $f_{\text {СппА }}$ системи електроживлення СППА, швидкість $v_{\text {сппс }}$ синхронного руху СН та СППА, глибина $H_{\text {СппА }}$ руху СППА, довжина $L_{\text {кт }}$ попущеної частини КТ, а також просторові координати корінного кінця КТ $\left\{x_{\mathrm{K}} ; y_{\mathrm{K}}\right.$; $\left.z_{\kappa}\right\}$, який закріплений на $\mathrm{CH}$, та ходового кінця КТ $\left\{x_{X} ; y_{X} ; z_{X}\right\}$, що закріплений на СППА. Вказані вимоги ТЗ являють собою умови обмеження, які забезпечать задовільне функціонування СППС для виконання необхідних замовнику задач.
Після опрацювання даних Т3 виконується конструювання складників СППС з існуючих елементів, вузлів чи систем, які доступні на світовому ринку, а також елементів, вузлів чи систем, що були раніше створені та випробувані організацією, яка $є$ головною у створенні СППС, чи організаціями-партнерами, що можуть ці елементи надати за певних умов (блок 2).

Наступним кроком $€$ аналіз режимів роботи СППС (блок 3). Тут виконується вибір найбільш енерговитратного, що визначається положенням СППА відносно $\mathrm{CH}$, в якому його РРК споживає найбільшу потужність (залежності (9) і (10)). Такий режим зазвичай виникає, коли апарат знаходиться попереду судна і рухається проти течії, намагаючись досягти найбільш віддаленої точки робочої зони.

Далі згідно із залежностями (11)-(15) виконується розрахунок оптимальної довжини КТ $L_{\text {Кторt }} \mathrm{i}$ розрахунок його діаметра (блоки 4 та 5). Потім перераховуються сили $F_{X}$ на ходовому кінці КТ для визначення упорів РП апарата (блоки 6 і 7).

Наступним етапом проектування $є$ перевірка правильності вибору РРК (блок 8). Якщо ця перевірка не задовольняє умови Т3, то обирається більш потужний РП чи змінюється конфігурація РРК СППА (блок 9).

Коли перевірка дає позитивний результат, виконується перехід до рівнянь існування СППС [14], за допомогою яких уже на ранніх стадіях проектування $є$ можливість визначити можливість створення СППС (блок 10). Тут установлюється відповідність проекту СППС енергетичному $E$, матеріальному $M$, інформаційному $I$ та функціональному $F$ критеріям існування СППС.

У разі, якщо рівняння існування задовольняють умови Т3 (блок 11), наступним кроком є формування документації щодо завершення ранньої стадії розробки та перехід до формування технічного проекту (блок 12).

Якщо за будь-яким критерієм рівняння існування характеристика СППС не відповідає умовам Т3, необхідно переходити до пошуку рішення, яке забезпечить виконання умов, що заявлені (блок 14). Основною дією цього рішення буде процес проектування елемента(-ів), що забезпечить виконання рівняння існування, яке призвело до необхідності пошуку рішення (блок 15).

Відсутність будь-якого рішення, що задовольняє умови ТЗ, викликає необхідність формування пропозицій до коригування останнього зі згоди замовника (блок 16). Згода замовника (блок 17) повертає проектанта до початку алгоритму, а відмова призводить до висновку про неможливість створення СППС.

Таким чином, методика проектування системи енергоживлення СППС, сутність якої відображають рівняння (1)-(15), є складником узагальненої методики проектування безекіпажних СППК на основі системного підходу.

Обговорення отриманих результатів. Основою результатів викладок, які розглянуті в основній частині статті, є намагання досягти комплексного підходу до 


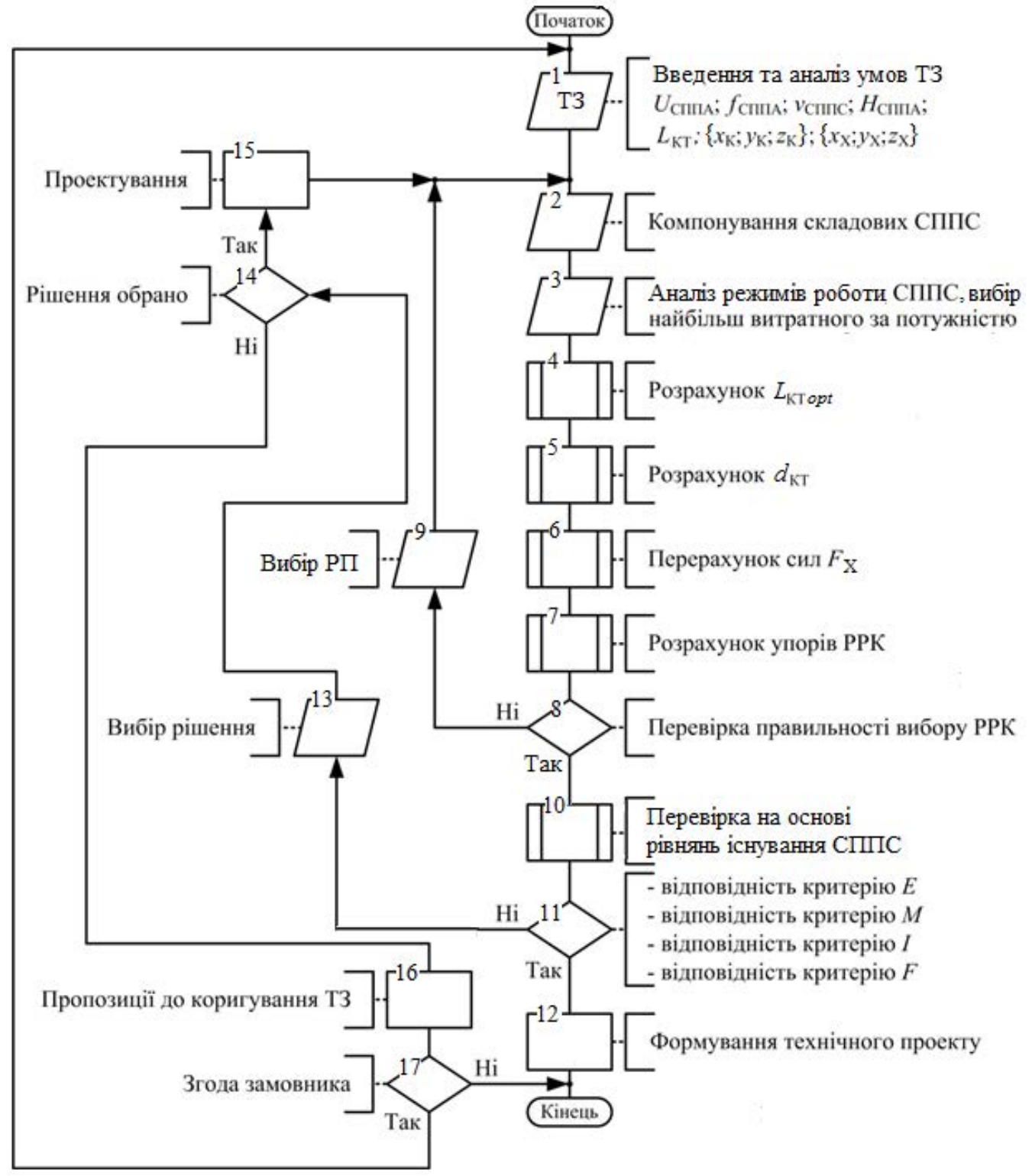

Рис. 2. Алгоритм визначення можливості створення самохідної прив'язної підводної системи

проектування самохідної прив'язної підводної системи 3 метою дати відповідь на головне питання, що полягає у можливості іiї створення. Це питання особливо актуальне на ранніх стадіях проектування, коли помилки в основних підходах можуть призвести до перевитрати трудових та фінансових ресурсів чи взагалі до неможливості більш-менш успішного закінчення проекту.

У багатьох літературних джерелах теоретично вирішені та підтверджені на практиці питання взаємосуперечливого впливу енергетичного складника системного підходу окремо на матеріальний, інформаційний та функціональний складники, але розгляд цього питання у комплексі наведено ще не було.

ВИСНОВКИ. Отримано основні енергетичні залежності для СППА та його кабель-троса, кабельної лебідки й поста енергетики і керування складників
СППС, які утворюють основу для рівняння енергетичного балансу СППС, що проектується.

Установлено множину основних експлуатаційних режимів СППС, які мають високе енергоспоживання, та наведено аналітичні залежності, що визначають порядок їх урахування у проектних розрахунках енергоживлення СППС.

Установлено аналітичні залежності для розрахунку конструктивних параметрів кабель-троса СППА, які враховують вплив сил гідродинамічної природи на енергетичні характеристики СППС.

Показано методологію використання отриманих енергетичних залежностей в узагальненій методиці проектування безекіпажних СППК на основі системного підходу, що дає змогу визначити можливість створення такої техніки вже на ранніх стадіях проектування. 


\section{Список літератури}

[1] Рижков, С.С. (Ред.). (2011). Створення універсальних транспортних суден $і$ засобів океанотехніки (монографія). Миколаїв : Видавництво НУК.

[2] Sulaiman, O., \& Saharuddin A. (2012). Power integrity requirement of new generation of ROV for deep sea operation. Global Journal of Researches in Engineering Automotive Engineering, 12 (3-B), 16-28.

[3] Бриллиантов, А.Н. (2005). Разработка и исследование основ построения энергетических систем подводных аппаратов: автореферат диссертации кандидата технических наук. Москва : Российская академия наук, институт океанологии им. П.П. Ширшова.

[4] Филоженко, А.Ю. (2010). Система электроснабжения привязных необитаемых подводных объектов: автореферат диссертации кандидата технических наук. Владивосток : Институт проблем морских технологий ДВО РАН.

[5] Правикова, А.А., Рулевский, В.М., Ляпунов, Д.Ю., \& Букреев, В.Г. Математическая модель системы электропитания телеуправляемого подводного аппарата с передачей энергии по кабель-тросу на переменном токе. Электротехника, доклады ТУСУРа, 20 (1), 131-135.

[6] Блінцов, О.В. (2017). Розробка методу математичного моделювання динаміки гнучкого зв'язку як елемента підводного комплексу. Восточно-Европейский журнал передовых технологий, 1/7 (85), 4-14. doi: 10.15587/1729-4061.2017.90291.

[7] Блинцов, В.С. (2007). Современные проблемы создания электрооборудования и автоматики подводных аппаратов. Радіоелектронні і комп 'ютерні системи, 5 (24), 90-98.

[8] Бабкін, Г.В. (2017). Управління успішними проектами створення складної техніки: монографія. Миколаїв : Видавництво Торубари В.В.

[9] Блинцов, А.В. (2012). Специализированный моделирующий комплекс для исследования эффективности системы управления подводной буксируемой системой. Збірник наукових працьь Наџіонального університету кораблебудування, 1 (442), 92-97.

[10] Блинцов, В.С., \& Магула, В.Э. (1997). Проектирование самоходных привязных подводных систем. Киев : Наукова думка.

[11] Егоров, В.И. (1981). Подводные буксируемые системы: учебное пособие. Ленинград : Судостроение.

[12] Блинцов, В.С. (1991). Особенности проектирования кабель-тросов привязных подводных аппаратов. Проектирование средств освоения океана, 76-79.

[13] Blintsov, V., \& Klochkov, O. (2019). Generalized method of designing unmanned remotely operated complexes based on the system approach. EUREKA : Physics and Engineering, 2, 43-51. doi:10.21303/2461-4262.2019.00878.

[14] Блінцов, В.С. (2016). Рівняння існування самохідної прив'язної підводної системи як оцінка можливості iї створення. Підводні технологї: промислова та циивільна інженерія, 3, 25-30.

(C) О. П. Клочков 